\title{
SOCIAL SCIENCE STUDENT TEACHERS' AWARENESS OF THE INTERTWINESS OF SOCIAL SCIENCE AND SOCIAL JUSTICE IN MULTICULTURAL SCHOOL SETTINGS
}

\author{
Titus Williams, Gregory Alexander, \& Wendy Setlalentoa \\ Central University of Technology Free State (South Africa)
}

\begin{abstract}
This qualitative study is an exploration of final year Social Science education students awareness of the intertwined nature of Social Science as a subject and the role of social justice in the classroom of a democratic South Africa. This study finds that South African Social Science teachers interpret or experience the teaching of Social Science in various ways. In the South African transitional justice environment, Social Science education had to take into account the legacies of the apartheid-era schooling system and the official history narrative that contributed to conflict in South Africa. Throughout the world, issues of social justice and equity are becoming a significant part of everyday discourse in education and some of these themes are part of the Social Science curriculum. Through a qualitative research methodology, data was gathered from Focus Group Discussion (FGD) sessions with three groups of five teacher education students in two of the groups and the third having ten participants from the same race, in their final year, specializing in Social Science teaching. The data obtained were categorised and analysed in terms of the student teacher's awareness of the intertwined nature of Social Science and social justice education. The results of the study have revealed that participants had a penchant for the subject Social Science because it assisted them to have a better understanding of social justice and the unequal society they live in; an awareness of social ills, and the challenges of people. Participants identified social justice characteristics within Social Science and relate to some extent while they were teaching the subject, certain themes within the Social Science curriculum. Findings suggest that the subject Social Science provides a perspective as to why social injustice and inequality are so prevalent in South Africa and in some parts of the world. Social Science content in its current form and South African context, emanates from events and activities that took place in communities and in the broader society, thus the linkage to social justice education. This study recommends different approaches to infuse social justice considerations Social Science; one being an empathetic approach - introducing activities to assist learners in viewing an issue from someone else's perspective, particularly when issues of prejudice or discrimination against a particular group arise, or if the issue is remote from learners' lives.
\end{abstract}

Keywords: Social science, social justice, awareness, teacher education, teaching.

\section{Introduction}

Since 1994 after the first democratic elections, there has been a significant redesigning process of the education and training landscape in South Africa. The period 1994 introduced a radically new historical era for all South Africans and most importantly, for schooling (Grades 1-12) in South Africa. The political thinking in 1994 was to abolish all the old that had been systemically linked with apartheid and to introduce new policies in all the various spheres in the country (Du Plessis, 2009). As schooling had been in dire straits for many years, government deemed it necessary that policy should be enacted to transform the national system of education and training. The latter needed to recognise that pedagogies, curricula and qualifications were not absolutes, but rather, that they were the result of decisions, as well as priorities, and therefore needed debating (Young \& Kraak, 2001; Wedekind, 2016).It was inevitable that a new curriculum for a new South African dispensation was welcomed and unavoidable, but the sine qua non was that diverse cultures, the background of learners, values in education and so forth, had to be taken into account (Harley \& Wedekind, 2004; Maphosa, Mudzielwana \& Netshifhefhe, 2014 ). The inclusion of social justice in teacher training programmes is viewed by many scholars as a contributor to preparing Social Sciences teachers to be agents of change who can assist the government of South Africa in achieving their educational objectives. 
Social justice generally embraces values, such as the equal worth of all citizens and their equal right to meet their basic needs. Kea, Campbell-Whatley and Richards, (2006) state that in the context of democratic education, teacher competencies such as sociocultural consciousness, adopting responsible teaching strategies, and having an affirming attitude towards learning from culturally diverse backgrounds, should form part of student teachers' professional development. Most advocates of social justice education note that preparing student teachers to teach in such learning environments and challenging oppression is difficult work, facing a multitude of barriers (Pace, 2014). As such, democratic education requires preservice teachers to lead and teach for social justice and in turn, combat oppressive practices, while creating an equal and dignified classroom environment.

The discipline of Social Science is better positioned to examine critical, social issues from multiple perspectives, explore past and present inequities, and propose possibilities for change in an increasingly globalised world (Agarwal-Rangnath, 2013). A significant stated goal of the Social Sciences is understanding the world, and it uses the term 'understanding' consciously because learning in Social Science involves more than simply memorising factual information. Factual knowledge is used as the foundation to support learners in their development of concepts and general understanding. Thinking skills are more imperative in the Social Sciences because learners use them to process facts in order that specific items of information may be related to one another in a variety of ways to become ideas (Ngulube, Mathipa \& Gumbo, 2015). Social Science as a school subject enables learners to deal with multifaceted social reality; reality that is not given but produced and reproduced under the influence of authoritative discourse of power and hegemony. By virtue of being 'social', the best place to teach students to question prevailing social norms, processes and practices, is in the Social Science classroom (Midford, James \& Hutchinson, 2018). The National Curriculum Statement (NCS), in the Curriculum and Assessment Policy Statement (CAPS) (2011) of South Africa state that the Social Sciences curriculum aims to provide opportunities for learners to look upon their own world with fresh and critical mindsets and perhaps more significantly, these policy documents aim to introduce learners to a world beyond their everyday realities. This study therefore aims at enticing teachers to embrace diversity in their classrooms.

\section{Aim of the study}

The aim of this qualitative study was to explore final year Social Science education students' awareness of the intertwined nature of Social Science as a subject and the manifestation of social justice imperatives in democratic classroom settings of South Africa.

\section{Methodology}

A qualitative method was employed for the purpose of this study. Assembling people belonging to similar backgrounds together to ascertain their insights, views, beliefs and attitudes in a coordinated discussion, is regarded as a focus group discussion (McMillan \& Schumacher, 2010). Participants in this type of research were, therefore, selected on the basis that they would have something to say on the topic; are within the age-range; have similar socio-characteristics; and would be comfortable talking to the facilitator and one another (Oladeji, 2012). The discussions were conducted with final year Social Science student teachers of one university. The participants were grouped according to racial groups. The rationale behind this was to garner perceptions based on South Africa's main racial groups. The Focus Group Discussions (FGD) had a white only group of five participants; a coloured group of five participants; and two groups of five each of black African participants. The rationale for having two groups of black Africans is due to a lack of forming an Indian group and because black Africans form the majority race group in South Africa. The aim of the research was to capture the richness and uniqueness of everyone's perception that emanated from the natural settings of the participants' environment. The division according to racial groups allowed participants to open-up and engage freely without fear of prejudice. Although the discussion was guided by a list of questions, the dialogue took the form of free conversation and the participants were encouraged to talk without restraint. The discussions were audio-taped and transcribed with the permission of the participants. This was done to capture the participants' responses. In total, 20 participants partook in the FGD. The participants (from both gender, different race groups and originated from rural and urban residential areas)) were obtained by means of purposive sampling, selected for fitting a particular profile, the FGD's were coded as follow: FGDA1-5; FGDB1-5; FGDC 1-5 and FGDD 1-5. 


\section{Presentation and analysis of results}

The presentation is done according to themes that were drawn from the analysis of discussion data. The same questions were posed to the different groups and as introduction the participants were asked to unpacked their views on Social Science as a subject, both as a learner and a teacher. We now briefly present some of the most pertinent findings in the form of two themes.

Theme 1: Social Science teaching and learning experience (Interesting, fascinating and related to politics)

This section is the presentation of how the teacher education participants view the teaching and learning of Social Science. Social Science is regarded as not similar to other school subjects and is viewed by many scholars as closely related to politics, which makes it a very awkward subject to teach or learn (Ucus, 2018). The participants (FGDA) indicated they found the subject to be interesting and challenging (FGDA A1, FGDA A2). Participant FGDA A3 said it was easy to understand and relate to because it relates to what is happening daily in communities, while participant FGDA A2 indicated it was interesting depending on the type of learners you have in your class. In relation to the views of the latter mentioned, participant FGDA5 highlighted the following aspects: "I found the subject very interesting and challenging, closely related to politics. I found myself at times very uneasy about expressing myself while teaching it during teaching practice." The participants (FGDB B5) responded that they also found the subject to be interesting with elements of politics and in admission to that, they (FGDB B1, FGDB B3 and FGDB B4) were of the opinion that they grew up in the township and were confronted daily by politics, made the Social Science classroom both as learners and teachers fascinating and enjoyable. The participant FGDB B3 further indicated that Social Science connects one to one's environment and community and that the subject can assist in shaping us. In this regard FGDB B2, stated the following: "I enjoy the subject SS because it is fascinating and one always learns something new about one's community, country and the world. I enjoy teaching it because of the interesting facts around Social Science and the impact it can make on the learners."

The participants (FGDC1 C2 and FGDC1 C4) concur with the two other groups that they found Social Science to be very interesting because of its relation to the human being and their environment (FGDC1 C2, FGDBC1 C5, FGDC2 C8 and FGDC2 C10). The participants (FGDC1 C4 and FGDC2 C6) indicated that the element of the subject's interrelatedness to politics, also contributed to their love for the subject. FGDC2 C7 articulated the following sentiment with regard to the nature of Social Science: "I enjoy SS because it makes me understand where I come from as a black person and why my parents and grandparents struggled that much. This subject opened up my horizons to how the earth operates and how people find in it a living space."

The other question that was posed during the focus group discussions was: Have you ever come across the term social justice during your training as a teacher? What is your opinion of social justice and its role in the teaching of a subject, such as Social Science?

Theme 2: Social justice in teacher training and its role in a subject, such as Social Science (Social justice consideration key in Social Science and social justice key in communities)

Education programmes seem to be adding statements about the importance of social justice to their mission, and a growing number of teacher education programmes are fundamentally oriented around a vision of social justice. The term is therefore predominantly used in multicultural settings to address matters of diversity and equality in communities. Hytten and Bettez (2011) argue that despite all the talk about social justice of late, it is often unclear in any practical terms what we mean when we invoke a vision of social justice or how this influences such issues as programme development, curricula, practicum opportunities, educational philosophy, social vision, and activist work.

Teacher education participants FGDA A3, FGDB B1, FGDB B3 and FGDC1 C3 in this study said that they had heard of social justice on other platforms but not as part of their teacher training programme. FGDC1 and $\mathrm{C} 5$ indicated that the term came up several times in debates related to communities and on television. When people refer to disadvantaged communities. Teacher education participant FGDA A2 disagreed with the latter statement and indicated the following: "No, but I think the first time I heard of social justice, might have been on television in a programme that discussed poverty in townships."

We of the view that despite the significant volume of social justice work in education, one of the pieces of the puzzle that seems to be missing is genuine dialogue across various positions that help us to build on each of their strengths, as well as to better acknowledge challenges and reflect on the complexities of education for social justice. 


\section{Discussion of findings}

Findings from the focus group discussion indicated that participants had a penchant for the subject Social Science because it assisted them to have a better understanding of social justice and the unequal society they live in; an awareness of social ills, and the challenges of people living in townships. This is further reinforced by Camicia and Dobson (2010) that learners should leave school with a clear sense of their rights and responsibilities as citizens and be prepared to challenge injustice and promote the common good. The subject Social Science provides a perspective as to why social injustice and inequality are so prevalent in South Africa and in some parts of the world. Gray (2017) reaffirms this notion and indicates that many scholars assert that teaching for social justice should be the core of teacher training, even it means teaching "against the grain". The most important goals of teacher training programmes are social responsibility; social change; and social justice.

It can be concluded that social justice has a particular role to play in education and in particular in Social Science because of the close link to society, communities and the broader population. Social Science content in its current form, from a South African perspective, emanates from events and activities that took place in communities and in the broader society, thus being relevant to the role communities should play. In the South African transitional justice environment, Social Science education also needed to take into account the legacies of the apartheid-era schooling system and the official historical narrative that had contributed to conflict. The segregation of schools and the concurrent underfinancing of black schools conspired to institutionalise deeply unequal education between whites and the majority of South Africans. Social Science education is seen as the hallmark of civilised society, the engine of social justice and economic growth, the foundation of our culture and the best investment that can be made in the future of a country. Studies have documented that regardless of the economic, ethnic, or cultural background, family involvement in a child's education is a major factor in determining success in all areas.

This study has revealed that the primary purpose of Social Science is to develop civic virtues; to assist learners to acquire knowledge, attitudes, values, habits and behaviour that are critical for maintaining a healthy, diverse, and dynamic society. The study additionally indicated that the primary mission of Social Science is to produce competent citizens, and the participants of this study revealed the importance of social impartialities in the Social Science classroom. Consequently, a recommendation would be that social justice considerations be included in the teaching and learning of Social Science, due to its intertwined nature and its value in achieving the governments' educational objectives. Institutions of higher learning should include social justice and multiculturalism in their teacher training programmes.

\section{Conclusion}

The findings of this study revealed that the participants appeared to show an enthusiasm for social justice considerations and the role it could possibly play in social cohesion and nation building. Participants from all racial groups appeared to show willingness to be change-agents society required in post-apartheid South Africa.

\section{References}

Agarwal-Rangnath, R. 2013. Social Studies, Literacy, and Social Justice in the Common Core Classroom: A Guide for Teachers. Kindle Edition.

Camicia, S. P., \& Dobson, D. 2010. Learning how to respond to current events: Partner journals between U.S. preservice teachers and children. Teaching and Teacher Education, 26, 576-582.

Du Plessis, T. 2009. Colonialism, Apartheid and Higher Education in South Africa. Transformation in Higher Education, 1 (1): 87-113.

Gray, R.A. 2017. Social justice educators' road through transformational educational pedagogy: What are the lessons learned? University of Pittsburgh. 205.

Harley, K. and Wedekind, V. 2004. Political change, curriculum change and social formation, 1990 to 2000. In Chisholm, L. (Ed.), Changing class: education and social change in post-apartheid South Africa. Cape Town: HSRC Press, pp.195-221.

Hytten, K., \& Bettez, S.C. 2011. Understanding Education for Social Justice. Educational Foundations, Winter-Spring.

Kea, C, Campbell-Whatley, G \& Richards, H. 2006. Becoming culturally responsive educators: Rethinking

McMillan, J.H. \& Schumacher, S. 2010. Research in Education: Evidence-Based Inquiry (7th ed.) New York: Pearson. 
Midford, S., James, S. \& Hutchinson, G. 2018. Key concepts in humanities and social sciences. La Trobe University Melbourne Australia. 90.

Ngulube, P., Mathipa, E.R. \& Gumbo, M.T. 2015. Theoretical and conceptual framework in the social and management sciences.

Oladeji, J.T. 2012. Investigation in Effectiveness of Questionnaire as a Method of Scientific Research. Education, 2 (1): 16-18

Teacher Education Pedagogy. Retrieved from http://www.niusileaderscape.org/docs/ Accessed 24 July 2017.

Ucus, S. 2018. Exploring Creativity in Social Studies Education for Elementary Grades: Teachers' Opinions and Interpretations. Journal of Education and Learning, 7(2): 111-125.

Young, M. \& Kraak, A.H. 2001. Education in retrospect: policy and implementation since 1990. HSRC, retrieved http://www.hsrcpublishers.ac.za/full_title_info.asp?id=1961 Accessed 1 August 2017 